\title{
KINERJA KOMISI PEMILIHAM UMUM DAERAH (KPUD) DALAM PEMILIHAN UMUM KEPALA DAERAH TAHUN 2012 DI KABUPATEN TAKALAR
} Muhammad Fajri Ichsan', Muhajirah Hasanuddin', Syamsir Rahim²

${ }^{1}$ Program Studi Ilmu Pemerintahan Fakultas Ilmu Sosial Dan Ilmu Politik Universitas Muhammadyah Makassar ${ }^{2}$ Program Studi Ilmu Administrasi Negara Fakultas Ilmu Sosial Dan Ilmu Politik Universitas Muhammadiyah Makassar Jl. Sultan Alaudin No. 259 Makassar 90221 Tlp. 0411-866972 ext. 107. Fax. 0411-8655888

\begin{abstract}
This study aims to determine the performance of the Takalar Electoral Commission in the implementation of Takalar General Election and to identify supporting and inhibiting factors of the performance of the Electoral Commission to success the election of Takalar. This research is a descriptive-quantitative, and the population in the study were also as the sample. Data were collected by observation, questionnaires and developed byinterviewing the respondent. The data were analyzed descriptive qualitatively in which analyzing all the data collected by the authors, and then presented in the form of frequency tabulation completed by the respond of respondents obtained from informants, interviews, and questionnaires. Results showed performance of Electoral Commission In Takalar Election is considered less successful and influenced by several supporting and inhibiting factors. The supporting factors for enhancing the Electoral Commision performance, namely: (a). Communication, dynamic relationship that is created between the policy and the environment as a form of policy. (b). Financial Resources, the use of efficient and effective budget and open in order to improve the performance of the Electoral Commission. (c). Human Resources, Improvement of human resources in the Electoral Commission is very important in regard to the targets to be achieved by the Electoral Commission in the Election process, while that the inhibiting factors in Electoral Commission performance enhancement, namely: (a). Financial Resources, General Election in Takalar delayed because the Election Fund has not been given . (b). Community activity, many of Takalar communities as fishermen who could not follow the General Election and blind-voter.
\end{abstract}

Keywords: performance, election commission, local election

\begin{abstract}
ABSTRAK
Penelitian ini bertujuan untuk mengetahui kinerja Komisi Pemilihan Umum Kabupaten Takalar dalam Pelaksanaan Pemilukada dan untuk mengetahui faktor yang mendukung serta menghambat kinerja Komisi Pemilihan Umum dalam mensukseskan pemilukada di Kabupaten Takalar. Penelitian ini adalah Deskriptif-Kuantitatif, Populasi dalam penelitian sekaligus merupakan sampel. Data dikumpulkan dengan menggunakan teknik berupa observasi, kuesioner serta dikembangkan dengan wawancara kepada responden. Data tersebut dianalisis secara Deskriptip kualitatif yaitu menganalisis semua data yang berhasil dikumpulkan penulis, dan selanjutnya disajikan dalam bentuk tabulasi frekuensi dilengkapi dengan tanggapan responden yang diperoleh dari hasil Informan, wawancara, dan kuesioner. Hasil penelitian menunjukkan Kinerja Komisi Pemilihan Umum dalam Pelaksanaan Pemilukada Di Kabupaten Takalar dikategorikan kurang berhasil dan dipengaruhi oleh beberapa faktor pendukung dan penghambat. Adapun faktor pendukung dalam peningkatan Kinerja KPU yaitu: (a). Komunikasi, Hubungan dinamis yang tercipta antara kebijakan dan lingkungan sebagai wujud dari kebijakan. (b). Sumber Daya Keuangan, penggunaan anggaran yang efisien dan efektif serta terbuka dalam upaya perbaikan kinerja KPU agar dalam pelaksanaannya. (c). Sumber Daya Manusia, Peningkatan sumber daya manusia di Komisi Pemilihan Umum sangat penting mengingat target yang ingin dicapai oleh KPU dalam proses pelaksanaan Pemilukada, Sedangkan yang menjadi faktor penghambat dalam peningkatan Kinerja KPU yaitu: (a). Sumber Daya Keuangan, Pemilukada di Kabupaten Takalar tertunda karena Dana Penyelenggaraan Pemilu belum diberikan. (b). Aktivitas Masyarakat, Banyaknya masyarakat Takalar sebagai nelayan yang tidak sempat mengikuti Pemilukada dan menjadi golput.
\end{abstract}

Kata kunci: kinerja, komisi pemilihan umum, pemilihan kepala daerah. 


\section{A. PENDAHULUAN}

Dalam Penyelenggara Pemilu diatur mengenai KPU, KPU Provinsi, dan KPU Kabupaten/ Kota sebagai lembaga penyelenggara pemilihan umum yang permanen dan Bawaslu sebagai lembaga pengawas Pemilu. KPU dalam menjalankan tugasnya bertanggung jawab sesuai dengan peraturan perundangundansgan serta dalam hal penyelenggaraan seluruh tahapan pemilihan umum dan tugas lainnya. KPU memberikan laporan Presiden kepada Dewan Perwakilan Rakyat. Kinerja Komisi Pemilihan Umum dilaksanakan oleh sebuah Komisi Pemilihan Umum (KPU) yang independen dan non partisan untuk mewujudkan kedaulatan rakyat guna menghasilkan suatu pemerintahan yang bersifat demokratis. Penyelenggaraan PEMILU yang bersifat LUBER JURDIL hanya dapat terwujud apabila penyelenggara PEMILU mempunyai integritas yang tinggi serta memahami dan menghormati hak-hak sipil dan politik dari warga negara. Penyelenggara PEMILU yang lemah berpotensi menghambat pemilu yang berkualitas. Berbeda pada Komisi Pemilihan Umum yang sebelumnya, saat itu Komisi Pemilihan Umum beranggotakan para fungsionaris peserta pemilihan umum yang tidak sesuai dengan aspirasi masyarakat, karena publik melihat begitu banyaknya unsur kepentingan yang mewaranai setiap kegiatan Komisi Pemilihan Umum sehingga sangat sering dalam pembahasan keputusan Komisi Pemilihan Umum harus menghadapi situasi rumit yang tidak dapat terselesaikan.

Mengenai wilayah kerja KPU, lembaga ini memiliki wilayah kerja meliputi seluruh wilayah Negara Kesatuan Republik Indonesia (NKRI). KPU bersifat independen sebagaimana termaktub dalam Pasal 3 ayat (3) UU No. 15 tahun 2011, yang bunyinya "Dalam menyelenggarakan Pemilu, KPU bebas dari pengaruh manapun berkaitan dengan tugas dan wewenangnya". Berbeda dengan peranan KPU, posisi lembaga ini dalam UU No. 15 tahun 2011 lebih mengakar karena adanya hubungan hierarkis antara KPU Pusat dan KPU Daerah. Hubungan hierarkis ini dinyatakan dalam Pasal 5 ayat (3) UU No. 15 tahun 2011 "Dalam menjalankan tugasnya, KPU dibantu oleh Sekretariat Jenderal; KPU Provinsi dan KPU Kab/Kota masing-masing dibantu oleh Sekretariat. Untuk menjalankan roda kegiatan KPU, lembaga tersebut dibantu Sekretariat Jenderal (Setjen). Secara struktural KPU terdiri dari KPU Pusat dan KPU Daerah. KPU pusat berkedudukan di Jakarta, KPU provinsi berkedudukan di ibukota Provinsi, KPU Kabupaten/ Kota berkedudukan di ibukota Kabupaten. Dalam melaksanakan tugasnya, KPU dibantu oleh Panitia Pemilihan Kecamatan (PPK) yang berkedudukan di setiap kecamatan, dan Panitia Pemungutan Suara (PPS) yang berkedudukan di setiap desa atau kelurahan, Setelah terbentuk, PPS membentuk kelompok Penyelenggara Pemungutan Suara. Selain PPK dan PPS, KPU membentuk Panitia Pemilihan Luar Negeri (PPLN). Tugas PPLN adalah menyelenggarakan Pemilu di Luar Negeri. Selanjutnya, PPLN membentuk Kelompok Penyelenggara Pemungutan Suara Luar Negeri (KPPSLN).

Hakekat Pemilukada adalah sarana perwujudan kedaulatan rakyat guna menghasilkan pemerintahan negara yang demokratis berdasarkan Pancasila dan UUD 1945 yang dilaksanakan secara LUBER JURDIL. Sesuai dengan Undang- Undang No. 15 Tahun 2011 tentang Penyelenggara Pemilu, terjadi perubahan dalam hal wewenang terkait regulasi yang mengatur tentang Pemilu. Dalam undang undang tersebut terjadi perubahan istilah Pilkada (Pemilihan Kepala Daerah dan Wakil Kepala Daerah) menjadi Pemilukada (Pemilihan Umum Kepala Daerah dan Wakil Kepala Daerah). Hal ini karena semua peraturan mengenai Pemilu di daerah berada pada kewenangan KPU Pusat, sedangkan KPU Kabupaten/ Kota tidak berhak mengaturnya. Jadi pada ranah dan rezim Pemilu kali ini istilah tersebut diganti dengan Pemilukada.

Pemilu dan Pemilukada Kabupaten Takalar merupakan Pemilukada yang diselenggarakan oleh KPU Kabupaten Takalar sebagai penyelenggara Pemilu yang bersifat nasional. tatap. dan mandiri, non partisan, tidak memihak, transparan, dan professional berdasarkan azas-azas pemilu demokratik dengan melibatkan partisipasi rakyat seluas-luasnya sehingga hasilnya dapat dipercaya oleh masyarakat. 
Sifat nasional KPU karena strukturnya ada di tingkat nasional (Pusat) kemudian ditingkat KPU Provinsi dan KPU Kabupaten/ kota begitu juga Sekretariat Jenderal KPU di pusat kemudian di sekretariat KPU Provinsi dan KPU Kabupaten/ kota. Sebagai sarana untuk perwujudan kedaulatan rakyat, Pemilukada merupakan agenda strategis demokratisasi di tingkat daerah yang nantinya diharapkan dapat membawa perbaikan-perbaikan dalam hal tata kelola pemerintahan dan kesejahteraan masyarakat. Jika melihat pada capaian yang tercatat di beberapa daerah, terutama sejak dilaksanakannya desentralisasi dan otonomi daerah, peran Kepala Daerah dalam mendorong inovasi program program pembangunan di daerah terasa demikian strategis dan signifikan.

Semakin terlihat jelas bahwa peran Kepala Daerah dalam praktek politik yang demokratis dan mengkaitkannya dengan agenda-agenda perbaikan kesejahteraan masyarakat demikian kuat. Pada komisi pemilihan umum akan menggelar Pemilukada secara langsung, Setelah sebelumnya, yaitu tahun 2002 hajatan Pemilukada secara langsung telah dilaksanakan. Untuk itu Komisi Pemilihan Umum (KPU) Kabupaten Takalar mengajak kepada seluruh warga Kabupaten Takalar untuk berpartisipasi aktif dalam setiap tahapan Pemilu dan Pemilukada Takalar. Masih tingginya angka pemilih yang tidak menggunakan hak pilihnya pada Pemilu dan Pemilukada terkait dengan faktor teknis dan faktor non teknis. Maka, pada tahun 2007 tersebut terjadi pengunduran pelaksanaan Pilkada yang membuat kondisi di masyarakat tidak menentu, sehingga tingkat pemilih yang tidak menggunakan hak pilihnya yaitu sebesar 167.143 dengan persentase 46,68 \%,3 Menyikapi hal tersebut menjadikan KPU Kabupaten Takalar dituntut bekerja lebih optimal untuk meningkatkan partisipasi masyarakat untuk menyalurkan hak pilihnya pada Pemilukada Tahun 2012. Untuk itu pada tahun 2012, KPU Kabupaten Takalar berusaha menciptakan iklim Pemilukada yang damai, sportif dan berbudaya.

Mencermati dari tahapan Pilkada tahun 2007 silam hanya meliputi dua tahapan saja yaitu masa pelaksanaan dan tahap penyele- saian. Namun Pemilukada Kabupaten Takalar pada tahun 2012 ini ada tiga macam tahapan kegiatan Pemilukada yang meliputi tahap persiapan, pelaksanaan dan penyelesaian, tentu merupakan sebuah tugas yang amat rumit dan memerlukan banyak strategi bagi KPU Kabupaten Takalar dalam melaksanakan tata kerja program dan kegiatan dari ke tiga tahapan Pemilukada tersebut. Yang pada akhirnya nantinya diharapkan dengan ketiga tahapan tersebut akan diperoleh hasil yang maksimal dalam Pemilukada.

Penulis tertarik meneliti terhadap persoalan di atas dengan harapan hasil penelitian dapat memberikan hasil dan berguna bagi Kabupaten Takalar.

\section{B. KERANGKA TEORITIS}

Kinerja berasal dari kata Job performance yaitu prestasi kerja yang dicapai seseorang. Performance diterjemahkan menjadi kinerja, juga berarti prestasi kerja, pelaksanaan kerja,pencapaian kerja atau hasil kerja, penampilan kerja (Lembaga Administrasi Negara ; 1992), Sedangkan menurut anwar prabu $(2004 ; 67)$ pengertian kinerja ( prestasi kerja ) adalah hasil kerja secara kualitas dan kuantitias yang dicapai oleh seorang pegawai dalam melaksanakan tugasnya sesuai dengan tanggung jawab sesuai dengan tanggung jawab yang diberikan kepadanya. Dalam melakukan suatu pekerjaan, seorang pegawai hendaknya memiliki kinerja yang tinggi. Akan tetapi hal tersebut sulit untuk dicapai, bahkan banyak pegawai yang memiliki kinerja yang rendah atau semakin menurun walaupun telah banyak memiliki pengalaman kerja dan lembaga pun telah banyak melakukan pelatihan maupun pengembangan terhadap sumber daya manusianya, untuk dapat meningkatkan kemampuan dan motivasi kerja pegawainya. Kinerja pegawai yang rendah akan menjadi sutau permasalahan bagi sebuah organisasi atau lembaga, karena kinerja yang dihasilkan pegawai tidak sesuai dengan yang diharapkan oleh organisasi. Untuk memberikan gambaran tentang kinerja pegawai, berikut ini adalah beberapa penjelasan yang berkaitan dengan kinerja pegawai. 
Dalam kamus bahasa inggris (Melinda ; 2005) kinerja diartikan sebagai "Performance is ability to perform, capacity achieve and desired result (Webster third). (New International dictionary ; 1966)". Kinerja didalam kamus bahasa Indonesia (1994 ; 503) dikatakan bahwa kinerja merupakan : (1) sesuatu yang dicapai (2) prestasi yang diperlihatkan (3) Kemampuan kerja. Sehingga dapat disimpulkan bahwa kinerja merupakan hasil kerja yang dihasilkan oleh pegawai atau karyawan dalam melakukan tugas dan tanggung jawabnya. Grounlud dalam bukunya "human competence engineering worthly performance" memberikan pendapatnya seperti yang dikutip oleh arif rahman (1997; 26) "kinerja adalah penampilan perilaku kerja yang ditandai oleh keluwesan gerak, ritme atau urutan kerja yang sesuai dengan prosedur sehingga diperoleh hasil yang memenuhi syarat berkualitas, kecepatan dan jumlah".

Untuk mengukur kinerja, dapat digunakan beberapa ukuran kinerja. Beberapa ukuran kinerja yang meliputi; kuantitas kerja, kualitas kerja, pengetahuan tentang pekerjaan, kemampuan mengemukakan pendapat, pengambilan keputusan, perencanaan kerja dan daerah organisasi kerja. Ukuran prestasi yang lebih disederhana terdapat tiga kreteria untuk mengukur kinerja, pertama; kuantitas kerja, yaitu jumlah yang harus dikerjakan, kedua, kualitas kerja, yaitu mutu yang dihasilkan, dan ketiga ketepatan waktu, yaitu kesesuaiannya dengan waktu yang telah ditetapkan. Istilah kinerja berasal dari kata job performance atau actual performance (prestasi kerja atau prestasi sesungguhnya yang dicapai oleh seseorang). Pengertian kinerja (prsetasi kerja) adalah hasil kerja secara kualitas dan kuantitas yang dicapai oleh seseorang karyawan dalam melaksanakan tugasnya sesuai dengan tanggung jawab yang diberikan kepadanya. Penilaian pegawai merupakan evaluasi yang sistimatis dari pekerjaan pegawai dan potensi yang dapat dikembangkan. Penilaian adalah proses penaksiran atau penentuan nilai, kualitas, atau status dari beberapa objek, orang ataupun sesuatu.

Kinerja juga dapat diartikan sebagai prestasi yang dapat dicapai organisasi dalam suatu periode tertentu. Prestasi yang dimaksud adalah efektifitas operasional organisasi baik dari segi manajerial maupun ekonomis operasional. Dengan kinerja kita dapat mengetahui sampai seberapa besar peringkat prestasi keberhasilan atau bahkan mungkin kegagalan seseorang karyawan dalam menjalankan amanah yang diterimanya.

Komisi Pemilihan Umum adalah lembaga Penyelenggara Pemilu yang bersifat nasional tetap dan mandiri sebagaimana dimaksud dalam Undang-Undang Nomor 12 Tahun 2008 tentang Pemerintahan daerah yang merupakan perubahan kedua atas Undang - Undang Nomor 32 tahun 2004 untuk menyelenggarakan pemilihan di Kabupaten/Kota dan diatur secara khusus dengan Undang-Undang No. 15 Tahun 2011 tentang Penyelenggara Pemilu. Dalam Undang-undang Nomor 15 Tahun 2011 Tentang Penyelenggara Pemilu diatur mengenai penyelenggara Pemilihan Umum yang dilaksanakan oleh suatu Komisi Pemilihan Umum (KPU) yang bersifat nasional, tetap, dan mandiri. Sifat nasional mencerminkan bahwa wilayah kerja dan tanggung jawab KPU sebagai penyelenggara Pemilihan Umum mencakup seluruh wilayah Negara Kesatuan Republik Indonesia. Sifat tetap menunjukkan KPU sebagai lembaga yang menjalankan tugas secara berkesinambungan meskipun dibatasi oleh masa jabatan tertentu. Sifat mandiri menegaskan KPU dalam menyelenggarakan Pemilihan Umum bebas dari pengaruh pihak mana pun.

Pemilihan Umum yang selanjutnya disebut Pemilu adalah sarana pelaksanaan kedaulatan rakyat yang diselenggarakan secara langsung, umum, bebas, rahasia, jujur dan adil dalam Negara Kesatuan Republik Indonesia berdasarkan Pancasila dan Undang - Undang Dasar Negara Republik Indonesia Tahun 1945. Pemilu telah berkembang menjadi bagian penting dari kehidupan suatu sistem politik. Dalam sebuah negara yang menganut demokrasi. Pemilu menjadi bagian yang tak terpisahkan. Tak ada demokrasi tanpa diikuti pemilu. Pemilu merupakan wujud paling nyata daripada demokrasi. Pemilu berhubungan erat dengan demokrasi karena pemilu merupakan wujud dari pelaksanaan 
demokrasi. Pemilu merupakan komponen penting di dalam negara demokrasi yang menganut system perwakilan sebab berfungsi sebagai alat penyaring bagi politikuspolitikus yang akan mewakili suara rakyat di lembaga perwakilan. Pemilu pada dasarnya adalah sarana untuk membangun kelembagaan politik yang demokratis. Pemilu sesungguhnya digelar untuk menjamin proses kompetisi dan pergantian kekuasaan yang dapat berjalan dengan aman, damai, dan professional.

Penyelenggaraan Pemilukada harus dilasanakan berdasarkan prinsip prinsip demokrasi sehingga prinsip demokrasi didalamnya harus ditegakkan dalam rangka menyelenggrakan Pemilukada. Pemilukada adalah instrument demokrasi dan hanya dengan Pemilukada pergantian kepemimpinan dapat berlangsung sesuaidengan prosedur demokrasi yang benar. Artinya, tidak ada mekanisme selain Pemilukada untuk memfasilitasi terjadinya pergantian kekuasaan secara damai dan demokratis. Dalam sejarah demokrasi, Pemilukada yang teratur merupakan cara yang damai dalam mengganti pemerintahan. Dengan demikian, Pemilukada menghindarakan penggunaan kekerasan dalam menggantikan pemerintahan yang tidak dikehendaki oleh rakyat lagi.

Didalam pelaksanaan pemilu kepala daerah tidak dapat dilepaskan keterkaitannya dengan (aparat) pelaksana KPU itu sendiri, khususnya yang telah berlangsung pada masa pergeseran dari rezim pemilihan kepala daerah ke rezim pemilihan umum. Untuk itu, pencermatan yang dilakukan terhadap pelaksanaan pemilu kepala daerah senantiasa dan diawali dan menjadi bagian tak terpisahkan dari perjalan pemilu dari tanah air beserta penyelenggara atau pelaksanaanya yang untuk waktu yang lama di jalankan oleh pemerintah. Baru beberapa tahun dilaksanakan oleh lembaga yang bersifat mandiri. Mencermati pelaksanaa pemilu yang berlangsung ditanah air selama ini, menunjukkan bahwa penyelenggaraan pemilu itu berbeda-beda di setiap masa. Berbeda dalam hal sistemnya maupun legitimasi formal yang di kandung dalam Undang-Undang sebagai dasar pelaksanaanya. Hal dapat dipahami sebagai Refleksi dari pergeseran dinamika dan perkembangan masa yang terus berubah dan hal itu sudah mestinya diikuti oleh sistem sosial masyarakat yang juga terus berkembang dinamis dari waktu ke waktu dengan mengakomodsikannya dalam bentu hukum, khususnya UndangUndang. Didalam pelaksanaanya, penyelenggara pemilu oleh pemerintah itu secara teknis diselenggarakan oleh kementerian dalam negeri, yang kedudukannya sebagai pembantu presiden. Netralitasnya ketika peran pemerintah pada bidang politik begitu besar karena kepentingan untuk melanggengkan kekuasaan tadi. Bahkan sebelum pemilu dilaksanakan pun sudah dapat ditebak bahwa pemenangnya adalah partai pemerintah dengan pemenang mutlak pula.

Peran serta masyarakat direkayasa sedemilkian rupa sehingga mencerminkan suara yang sangat besar sebagai bagian dari upaya menamkan kesan bahwa pemenangnya benar-benar legitimate dan memperoleh dukungan sangat kuat dari rakyat. Pada perkembangan berikutnya setelah sekurangnya empat kali penyelenggara pemilu, dibentuk Ksomisi Pemilihan Umum (KPU) yang merupakan lembaga yang pada awal pembentukanya beranggotakan orang-orang yang non partisan dan kebayakan dari kalangan pengurusan Tinggi Lembaga Swadaya Masyrakat (LSM). Kewenanganya boleh disebut cukup besar, pada awal meneyelenggarakan Pemilu. Namun pada waktu itu, terutama substansi yang berhubungan dengan dengan orientasi baragam dari parpol pemilu dapat diselasaikan dengan baik. Bahkan perkembangan berikutnya terjadi pelenggaran hukum oleh Anggota KPU yang membawa tindak pidana korupsi. Suksesnya Penyelenggaran pemilu tidak cukup untuk menutup cacat hukum yang membawa beberapa anggotanya ke penjara. Sebuah pengalaman berharga yang membawa persepsi beragam tentang modus tindakan korupsi pada lembaga penyelenggara pemilu. Berbagai dari yang disampaikan untuk menghindarkan diri ternyata kandas karena beberapa anggota KPU harus menerima kenyataan bahwa mereka terindikasi, dan akhirnya terbukti secara yuridis melakukan tindak pidana dan untuk itu harus menjalani hukuman.Sejak awal 
pembentukan KPU untuk pemilu tahun 1999, mengemuka berbagai permasalahan. Pada satu sisi hal ini dapat dimaklumi karena lembaga tersebut baru saja dibentuk dan masih mencari style kinerja yang mapan dan terukur.

Sebagai konsekuensi ketentuan konstitusional bahwa penyelenggara Pemilu bersifat nasional, tetap, dan mandiri, Pasal 5 ayat (1) UU Nomor 15 Tahun 2011 menyatakan bahwa KPU, KPU provinsi, dan KPU Kabupaten/kota bersifat hierarkis. Oleh karena itu KPU, KPU provinsi, dan KPU Kabupaten/kota adalah satu kesatuan organisasi berjenjang walaupun telah ditentukan pembagian tugas dan tanggung jawab masing masing oleh undangundang. KPU provinsi adalah organ dari KPU yang harus melaksanakan dan mengikuti arahan, pedoman, dan program dari KPU, terutama dalam hal pelaksanaan Pemilu DPR, DPD, DPRD, serta Presiden dan Wakil Presiden. Di sisi lain, KPU provinsi harus mengkoordinasikan dan memantau pelaksanaan tugas KPU Kabupaten/kota.

Di berbagai Negara di dunia sebetulnya pelaksanaan pemilu yang demokratis tidak mengharuskan adanya lembaga yang kita kenal sekarang dengan sebutan Badan Pengawas Pemilu untuk tingkat nasional dan Panitia Pengawas Pemilu untuk tingkat provinsi dan Kabupaten/kota untuk menjamin pelaksanaan pemilu yang jujur dan adil. Bahkan dalam praktek pemilu di Negaranegara yang sudah berpengalaman melaksanakan pemilu yang demokratis, keberadaan lembaga Pengawas Pemilu tidak dibutuhkan. Namun para perancang undang-undang pemilu sejak Orde Baru sampai sekarang menghendaki lembaga Pengawas Pemilu itu eksis, karena karena posisi maupun perannya dinilai strategis dalam upaya pengawasan pelaksanaan pemilu sesuai aturan perundangundangan yang berlaku terutama menegakkan asas pemilu yang luber dan jurdil.

Potensi kisruh akibat ketidak akuratan DPT akan tetap ada selama basis data yang digunakan untuk menyusun DP4, DPS dan DPT ini juga masih lemah. Dengan tingkat persebaran penduduk yang tidak merata, mobilitas yang tinggi di perkotaan, serta tingginya biaya untuk melakukan verifikasi, maka asumsi yang harus digunakan adalah bahwa daftar pemilih tidak pernah tetap. Padahal data pemilih disusun berdasarkan sensus penduduk yang dilakukan 10 tahun sekali. Maka tidak ada pilihan lain selain melakukan perbaikan administrasi kependudukan agar menjadi lebih modern. Nomor Induk Kependudukan (NIK), yang sudah dimulai digunakan pada Pemilu 2009, musti di dalam bentuk data digital yang tersentralisir sehingga mudah diverifikasi. Berikut merupakan kerangka pemikiran dari penulis yang penulis lakukan.

Pelaksanaan kegiatan Bimbingan Teknis (Bimtek) bagi Anggota Panwaslu Provinsi dan Kabupaten/Kota Panwaslu Kada Provinsi dan Kabupaten/Kota harus bisa menjaga ekspektasi masyarakat terhadap eksistensi kelembagaan Bawaslu. Materi hasil Bimbingan Teknis hendaknya dijadikan pedoman pengawasan Pemilu agar anggota Panwaslu Kada bisa bekerja dengan baik. Inti dari kegiatan Bimbingan teknik ialah Bawaslu dan Panwaslu bisa bekerja secara sinergis, saling memberi masukan satu sama lain. Dan yang terpenting adalah membentuk integritas individu dalam pelaksanaan pengawasan Pemilu Kada sehingga selalu ada kesadaran untuk bekerja dengan baik. Berkenaan dengan pembentukan danpenetapan Panwaslu Kabupaten/Kota, Bawaslu mempunyai tugas dan kewajiban untuk memberikan pembekalan bagi Panwaslu yang telah terbentuk yang melaksanakan Pemilu yang telah terbentuk yang melaksanakan Pemilu Kada Kabupaten/ Kota Tahun 2012. Pembekalan ini akan sangat bermanfaat bagi setiap Anggota Panwaslu dalam melaksanakan tugas dan kewajibannya sebagai pengawas pemilu sesuai dengan peraturan perundangan yang berlaku,". Kepala Sekretariat Bawaslu mengatakan bahwa tujuan bimbingan teknis ini adalah untuk meningkatkan pemahaman, pengetahuan dan ketrampilan serta menanamkan nilai-nilai integritas, dan soliditas, netralitas Anggota Panwalu Kada dengan baik sesuai dengan peraturan perundang-undangan.

Kekurangan dalam kinerja KPU yang sudah dibahas sebelumnya, kiranya dapat 
diukur melalui membentuk Panitia Pemilihan Indonesia yang selanjutnya disebut PPI dan mengkoordinasikan kegiatan Pemilihan Umum mulai dari tingkat pusat sampai di Tempat Pemungutan Suara yang selanjutnya disebut TPS. Tugas KPU adalah mengkoordinasikan kegiatan Pemilihan Umum dari tingkat pusat hingga TPS di berbagai daerah seluruh Nusantara. Melihat kenyataan yang ada, nampaknya memang kinerja KPU dapat ditetapkan sebagai sebuah kegagalan, mengingat kisruh penetapan DPT dan pelaksanaan PEMILU yang mengakibatkan "menurun"nya tingkat partisipasi politik. Hal tersebut menjadi kegagalan KPU dalam melaksanakan membentuk Panitia Pemilihan Indonesia yang selanjutnya disebut PPI dan mengkoordinasikan kegiatan Pemilihan Umum mulai dari tingkat pusat sampai di Tempat Pemungutan Suara yang selanjutnya disebut TPS.

\section{METODE PENELITIAN}

Tipe Penelitian yang digunakan adalah tipe penelitian Deskriptif Kualitatif, yaitu tipe penelitian yang berusaha menggambarkan secara jelas tentang Kinerja Komisi Pemilihan Umum dalam Pelaksanaan Pemilukada di Kab. Takalar. Dasar penelitian adalah penelitian yang dilakukan untuk mengetahui nilai variabel mandiri, baik satu variabel atau lebih (independen) tanpa membuat perbandingan, atau menghubungkan antara variabel yang satu dengan variabel yang lainnya. Mengingat fokus dari penelitian ini adalah kinerja komisi pemilihan umum dalam pelaksanaan pemilukada di Kabupaten Takalar, maka yang menjadi populasi dalam penelitian ini adalah pegawai pada kantor Komisi Pemilihan Umum (KPU), Tim sukses para kandidat, Tokoh Masyarakat (LSM), Panwaslu, dan Calon Kandidat Kepala Daerah dan Wakil Kepala Daerah yang berjumlah 42 Orang. Teknik penarikan sampel dalam penelitian ini dilakukan secara sampel kuota mengingat jumlah populasi yang telah kami tentukan, maka seluruh populasi adalah sampel jenuh yaitu sebanyak 42 orang Responden, terdiri dari: Komisi Pemilihan Umum (KPU) sebanyak 5 orang, Tim sukses para Kandidat, sebanyak 7 orang, Tokoh Masyarakat, sebanyak 13 orang, Panwaslu, sebanyak 10 orang dan Calon Kandidat, sebanyak 7 orang, informan: Komisi Pemilihan Umum (KPU), Kepala Dinas Kependudukan dan Catatan Sipil, Badan Pemenangan Pemilu (Bappilu), Tokoh Masyarakat, Calon Kandidat dan Badan Pengawas Pemilu (Bawaslu). Adapun Jenis data yang digunakan dalam penelitian ini terdiri atas : Data kualitatif serta kualitatif serta sumber data terdiri dari atas : Data primer dan Data Sekunder. Teknik Pengumpulan Data : Dalam penelitian ini data-data yang diambil dapat digolongkan menjadi dua bagian yaitu data sekunder data primer. Data sekunder adalah data yang bersumber dari kepustakaan (library study), sedangkan data primer adalah data yang bersumber dari studi lapang (field Research) Studi lapang yang dilakukan dengan tujuan untuk memperoleh data yang akurat mengenai objek yang diteliti dengan menggunakan teknik-teknik sebagai berikut: Observasi, Wawancara dan kuesioner. Adapun teknik analisis data yang penulis gunakan dalam mengelola adalah teknis analisis deskriptif kuantitatif dari data hasil kuesioner yang diedarkan dan didukung oleh hasil observasi dan wawancara informan setelah itu dikumpulkan kemudian dianalisis dan diolah melalui tabel frekuensi.

\section{HASIL DAN PEMBAHASAN}

\section{KINERJA KOMISI PEMILIHAN UMUM DALAM PELAKSANAAN PEMILUKADA KABUPATEN TAKALAR}

Dalam menentukan kinerja Komisi Pemilihan Umum tentunya dengan memperhatikan tahapan-tahapan kerja yang telah terstruktur yaitu Persiapan, Pelaksanaan, dan Penyelesaian.

\section{Persiapan}

Berikut wawancara penulis dengan Informan mengenai persiapan KPU sebagaimana dikemukakan oleh salah seorang anggota KPU Kabupaten Takalar bahwa:

"KPU Kabupaten Takalar telah membuat persiapan yang matang dalam pesta demokrasi rakyat yaitu Pemilukada, dimana kami semua para pemangku amanah yang dipercayakan 
untuk menyelenggarakan pemilu telah bekerja sesuai dengan tahapan-tahapan prosedurnya secara bertanggung jawab dan profesional". (Wawancara, Hj. A. TC S, , 13 Desember 2012)

Persiapan yang dilakukan oleh KPU saat ini berjalan dengan baik meskipun ada beberapa masalah yang muncul pada persoalan teknisnya. Namun menurut penulis bahwa persiapan yang dilakukan KPU belumlah cukup untuk penyelenggaraan Pemilukada dari segi pendataan daftar pemilih tetap. KPU perlu lebih meningkatkan kinerja secara profesional dalam mempersiapkan segala sesuatunya untuk menghasilkan pemilukada yang baik.

\section{Pelaksanaan}

Berikut wawancara penulis dengan Informan mengenai pelaksanaan KPU sebagaimana dikemukakan oleh salah seorang anggota KPU Kabupaten Takalar bahwa:

"Kami bekerja semaksimal mungkin dalam pelaksanaan Pemilukada ini dengan menjalin komunikasi yang baik mulai dari Ketua KPU hingga Ketua KPPS dimana segala bentuk masalah sekecil mungkin akan kami atasi secepatnya, proses kerja kami terstruktur dengan baik, dengan proses penentuan Ketua KPPS dilihat dari tingkat pendidikan dan pengalaman sebelumnya agar pelaksanaan Pemilukada di TPS dapat berjalan lancar dan baik". (Wawancara, A N, 13 Desember 2012).

Hasil kerja secara kualitas dan kuantitias yang dicapai oleh seorang pegawai dalam melaksanakan tugasnya sesuai dengan tanggung jawab yang diberikan kepadanya. Hal ini menunjukkan bahwa pelaksanaan Pemilukada tersebut berhasil akan tetapi menurut penulis jangan hanya menentukan Ketua KPPS dari sisi pendidikan dan pengalamannya akan tetapi juga menganalisa dari sisi kenetralan individu yang akan menjadi Ketua KPPS.

\section{Penyelesaian}

Berikut wawancara penulis dengan Informan mengenai persiapan KPU sebagaimana dikemukakan oleh Sekretaris KPU Kabupaten Takalar bahwa:
"Terjadi sengketa pemilu dari kandidat nomor urut 4 yaitu H. Syamsari Kitta, S,pt, MM, dan Ir. H. Hamza Barlian, MS dan yang di usung partai politik PKS,PKB,dan PDIP. dan nomor urut 6 yaitu Drs. H. Andi Makmur A,S, dan H. Nashar A.Baso, SH,M,si yang di usung partai politik PPK,PDK,PKNU, dan PARTAI DEMOKRAT. Hasil yang menang tidak cukup dari 30\% dan juga permasalahan di TPS yang terdapat anak-anak yang belum cukup umur terdaftar sebagai pemilih, serta pemilih yang bukan orangnya dalam daftar ikut memilih (Joki pemilih).

Prinsip demokrasi yaitu dari rakyat, oleh rakyat dan untuk rakyat. Hal ini menjelaskan di atas penyelesaian Pemilukada di Kabupaten Takalar telah mencapai target, Menurut penulis walaupun kadangkalanya dalam suatu kompetisi pasti ada yang kalah dan ada yang menang, maka dari itu KPU dalam penyelesaiannya harus mampu mengembil sikap dalam penyelesaian sengketa yang terjadi sesuai dengan aturan yang ditetapkan dan telah disepakati bersama agar mewujudkan proses demokrasi yang baik.

\section{FAKTOR PENGHAMBAT DAN FAKTOR PENDUKUNG KINERJA KOMISI PEMILIHAN UMUM DALAM PELAKSANAAN PEMILU- KADA KABUPATEN TAKALAR}

Dari hasil kuesioner dan wawancara yang peneliti lakukan, diketahui bahwa faktor pendukung dan penghambat Kinerja Komisi Pemilihan Umum Dalam Pelaksanaan Pemilukada Di Kabupaten Takalar. Faktor Pendukung Kinerja Komisi Pemilihan Umum Dalam Pelaksanaan Pemilukada Kabupaten Takalar yaitu sebagai berikut:

\section{Komunikasi}

Hubungan dinamis yang tercipta antara kebijakan dan lingkungan sebagai wujud dari kebijakan, dalam hal ini terutama hubungan atau interaksi antara penyelenggara-penyelenggara kebijakan dan yang menetapkan kebijakan. Banyaknya responden yang mengatakan sangat baik maka interaksi antara penyelenggara Pemilihan Umum dan Calon Kepala Daerah dan Wakil Kepala Daerah dapat dikatakan sudah sangat baik. Hal ini sependapat 
dengan yang dikatakan dengan informan kami dalam wawancara yang kami lakukan, bahwa:

"Hubungan yang terjalin antara Komisi Pemilihan Umum dengan Calon Kepala Daerah dan Wakil Kepala Daerah saat ini sangat baik. KPU berusaha sangat tanggap dalam menjalin komunikasi dalam proses penyeleksian dan pelaksanaan dengan tujuan agar informasi dalam bentuk peraturan KPU yang berlaku dapat tersosialisasi semaksimal mungkin". (Wawancara, Agsl,19 Desember 2012).

Pencapaian tujuan peningkatan Negara yang berdemokratis yang dituangkan dalam proses Pemilihan Umum untuk menentukan Kepala Daerah dan Wakil Kepala Daerah dilaksanakan secara jujur, adil, terbuka, efektif dan profesional. Menurut saya bahwa pada dasarnya, ketika suatu proses demokratisasi tidak berjalan sesuai dengan tujuannya, maka yang menjadi masalah adalah pola komunikasi informasi yang seiring tidak dikomunikasikan dengan baik kepada peserta Kandidat Calon Kepala Daerah dan Wakil Kepala Daerah. Untuk itu diharapkan adanya perbaikan pola komunikasi kebijakan yang lebih baik.

\section{Sumber Daya Finansial}

Pada kenyataan, sumber daya finansial memainkan peranan yang sangat penting untuk menggerakkan lembaga/organisasi dalam suatu kegiatan. Banyaknya responden yang mengatakan sangat penting maka dalam meningkatkan Kinerja KPU dalam penyelenggaraan Pemilu sangat ditunjang oleh sumber daya finansial, sebagaimana diutarakan oleh Sekretaris KPU Takalar bahwa:

Dengan melihat pertambahan penduduk sekarang ini yang semakin meningkat pesat, sangat diperlukan adanya pendanaan yang memadai untuk memaksimalkan kinerja KPU Kabupaten Takalar dalam penyelenggaraan pemilukada, maka dari itu anggaran yang diperlukan juga semakin bertambah. Penetapan Pemilihan Umum Kepala Daerah dan Wakil Kepala Daerah pada tanggal 12 Juli 2012 ditunda ke tanggal 04 Oktober 2012 dikarenakan dana yang akan digunakan belum diturunkan ke KPU Kabupaten Takalar. (Wawancara, Agsl, 25 Oktober 2012).
Sarana dan prasarana KPU sangat diperlukan dalam pemenuhan kebutuhan penyelenggaraan Pemilu. Namun yang perlu diperhatikan menurut saya adalah penggunaan anggaran yang efisien dan efektif serta terbuka dalam upaya perbaikan kinerja KPU agar dalam pelaksanaannya sesuai dengan tingkat kemaksimalkan kerjanya dan tidak terlalu merugikan sumber keuangan Negara. Anggaran Penyelenggaraan Pemilukada di Kabupaten Takalar sudah lebih dari yang diharapkan karena proses pemilukada hanya dilaksanakan dalam satu putaran saja yang hanya menghabiskan Rp. 6.999.840.838 dan putaran kedua tidak dilaksanakan jadi sisa anggaran KPU yang tidak dipergunakan sebanyak Rp. 1.999.264.680.

\section{Sumber Daya Manusia}

Sumber daya yang paling utama dalam menjalankan suatu Lembaga/Organisasi adalah sumber daya manusia karena organisasi tidak digerakkan oleh mesin dan teknologi, tetapi oleh manusia. Dengan demikian, cara organisasi dalam mendapatkan manusia yang memiliki kemampuan dan integritas tinggi merupakan tantangan utama dalam hal manajemen Lembaga/Organisasi. Melalui sumber dayanya diharapkan dapat menciptakan lapangan kerja bagi semua masyarakat. Peningkatan sumber daya manusia di Komisi Pemilihan Umum sangat penting mengingat target yang ingin dicapai oleh KPU dalam proses pelaksanaan Pemilihan Umum Kepala Daerah dan Wakil Kepala Daerah. banyaknya responden yang mengatakan sangat baik maka peningkatan sumber daya masyarakat yang sejalan dengan ketersediaan lapangan kerja dapat dikatakan sudah sangat baik. Dalam wawancara kami dengan Ketua KPU, bahwa:

Komisi Pemilihan Umum Kabupaten Takalar berusaha meningkatkan sumber daya manusia untuk peningkatan kesejahteraan masyarakat dalam menunjang kinerja KPU. Tentu hal ini didukung dengan usaha membuka peluang bagi masyarakat takalar untuk mendapatkan kesempatan lapangan pekerjaan. (Wawancara, FA,17 Oktober 2012).

Peningkatan Kinerja adalah suatu strategi untuk mencapai tujuan dalam memperlancar 
proses pelaksanaan pemilihan umum. Menurut saya Kinerja KPU Kabupaten Takalar dilakukan dalam semua tahapan, mulai dari persiapan, pelaksanaan dan penyelesaian dari semua tahapan program dan jadwal penyelenggaraan pemilihan umum Kepala Daerah dan Wakil Kepala Daerah Kabupaten Takalar. Peningkatan sumber daya manusia/pelaksana menjadi begitu penting dalam pelaksanaan penyelenggaraan Pemilu oleh KPU.

\section{FAKTOR PENGHAMBAT KINERJA KOMISI} PEMILIHAN UMUM KABUPATEN TAKALAR

\section{Sumber Daya Keuangan}

Sumber daya keuangan merupakan hal esensial untuk menjamin aktivitas kerja Komisi Pemilihan Umum. Peran dan konstribusi daya ini penting sekali, mengingat hampir setiap ruang gerak kerja membutuhkan pendanaan. Mulai dari sewa gedung kantor dan pemeliharaannya, serta peralatan kantor, rapat-rapat kerja, dan gaji pegawai. Sumber daya keuangan sangat diperlukan dalam proses penyelenggaraan Pemilukada di Kabupaten Takalar karena segala bentuk aktivitas apabila tidak di dukung oleh pendanaan maka kerja yang akan dilakukan tidak dapat berjalan lancar karena semuanya memerlukan biaya. Mengenai hal ini informan kami yaitu salah satu pegawai KPU dalam wawancara mengatakan bahwa:

"Penyelenggaraan pemilukada di Kabupaten Takalar tertunda dikarenakan dana pemilukada belum turun sehingga jadwal pelaksanaannya yang semestinya dijadwalkan tanggal 12 Juli 2012 diundur pada tanggal 04 Oktober 2012. (Wawancara, SI ,14 November 2012).

Sumber daya keuangan merupakan hal esensial untuk menjamin aktivitas politik yang berkelanjutan, konstribusi sumber daya ini penting sekali. Akan tetapi menurut penulis walaupun anggaran yang dipersiapkan untuk menyelenggarakan Pemilukada banyak tetapi apabila anggota KPU tidak mampu untuk mengelolanya dengan baik maka hasilnya pun akan tidak baik, maka dari itu KPU harus mampu mengelola keuangan yang ada secara efektif dan efisian.

\section{Aktivitas Masyarakat}

Aktivitas masyarakat yang dimaksud adalah kegiatan masyarakat dalam kehidupan sehari-hari guna memenuhi kebutuhan hidup baik itu primer maupun sekunder. Sebagian besar masyarakat Kabupaten Takalar berprofesi sebagai nelayan dilihat dari letak geografisnya yang tinggal dipesisir untuk itu agar dapat memenuhi kebutuhan hidupnya maka mereka pergi melaut. Kendala yang dihadapi KPU Takalar saat ini masyarakat tidak dapat mengikuti Pemilukada pada bulan juli karena pada bulan juli masyarakat pergi mencari ikan di laut dan mempengaruhi jumlah peserta wajib pilih yang akan datang memberikan partisipasi politiknya maka dari itu diundurlah pemilihan umum kepala dan wakil kepala daerah pada bulan oktober. pernyataan informan kami dalam wawancara, bahwa:

"Banyak masyarakat yang tidak dapat mengikuti Pemilukada pada bulan Juli 2012 karena pergi melaut mencari ikan sebagai sumber pendapatannya ini mengakibatkan jumlah pemilih berkurang dan menghambat proses sosialisasi yang dilakukan KPU dalam partisipasi masyarakat dalam berdemokrasi." (Wawancara, Tjdn, 14 November 2012).

Dalam upaya peran dan partisipasi masyarakat dilakukan peningkatan sosialisasi oleh KPU. Menurut saya bahwa dalam upaya ini diperlukan suatu pola yang tepat pada sasaran dan tenaga yang ahli dalam bidangnya, agar tujuan sosialisasi yang ingin dicapai KPU dapat maksimal dan efektif.

\section{E. KESIMPULAN}

Berdasarkan hasil penelitian pada bagian sebelumnya, maka penulis dapat menyimpulkan bahwa:

Kinerja Komisi Pemilihan Umum Dalam Pelaksanaan Pemilukada di Kabupaten Takalar dapat meningkatkan proses demokrasi di Indonesia dengan efektifitas proses pelaksanaan yang lebih baik. Namun di sisi lain kinerja KPU ini masih perlu di tingkatkan dalam hal ini persiapan yang lebih baik karena masih ada terjadi permasalahan yaitu proses penyelenggaraan Pemilukada masih belum optimal dari keakuratan daftar pemilih yang di dalamnya 
terdapat pemilih yang masih tergolong anakanak yang belum memenuhi syarat untuk menjadi peserta pemilu, dan juga di temukan di TPS peserta pemilu yang bukan orang sebenarnya yang telah terdaftar. Untuk itu dalam meningkatkan kinera KPU perlu adanya sistem pelaksanaan yang lebih profesional dan sistem pengawasan yang lebih baik.

Faktor pendukung dalam pelaksanaan pemilukada di Kabupaten Takalar yaitu: (a). Komunikasi, (b). Sumber Daya Finansial, dan (c). Sumber daya manusia. Sedangkan yang menjadi faktor penghambat dalam pelaksanaan Kinerja KPU adalah (a). Sumber daya keuangan. (b). Aktivitas Masyarakat.

\section{DAFTAR PUSTAKA}

Ahmad, Nadir, 2005, Pilkada Langsung dan Masa Depan Demokrasi di Indonesia, Malang : Penerbit Averroes Press

Arikunto, Suharsimi. 2002. Prosedur Penelitian Suatu Pendekatan Praktis. Jakarta : Rineka Cipta,

Bratakusumah, Dedy S, dan Solihin, 2002, Otonomi Penyelenggaraan Pemerintahan Daerah,Jakarta: Gramedia PustakaUtama

Budiardjo, Miriam. 1996. Dasar-Dasar Ilmu Politik. Jakarta : Gramedia Utama.

Duverger, Maurice. 1998, Sosiologi Politik, Jakarta : Raja Grafindo Persada.

Faisal Sanifah,1990. Penelitian Kualitatif; Dasar-dasar dan Aplikasinya. Malang: YA3

Fathurrohman, Deden \& Sobari,Wawan. 2002. Pengantar Ilmu Politik. Malang:UMM Press

Hikam, M.A.S. 2007, "Pemilihan Umum dan Legitimasi Politik" Dalam Pemilihan Umum di Indonesia, Jakarta : PPW LIPI \& Sinar Grafika.
Meyer, Thomas. 2002 Demokrasi; Sebuah Pengantar untuk Penerapan. Jakarta: Friedrich Ebert Stiftung.

Nuridin, Rachamad K. Dwi Susilo, Tri Sulistyaningsih, 2006, Kebijakan Elitis Politik Indonesia, Malang : Penerbit Pustaka Pelajar-FISIP UMM

Prihatmoko, Joko. 2005. Pilkada Langsung. Yogyakarta: Pustaka Ilmu.

Rakhmat, Jalaluddin. 1993. Metode Penelitian Komunikasi. Bandung: Remaja Rosda Karya

Ramlan Surbakti dkk, 2008, Perekayasaan Sistem Pemilihan Umum Untuk Pembangunan Tata Politik Demokratis, Partnership for Governance Reform Indonesia

Rauf Maswadi, dan Nasrun Mappa. 2005. Indonesia dan Komunikasi Politik, Jakarta: Gramedia Pustaka Utama.

Sarundajang, 2012, Pilkada Langsung Problematika dan Prospek, Jakarta : Kata Hasta Pustaka

Salossa, Daniel. 2005, Pilkada Langsung. Yogyakarta : Penerbit Media Pressindo

Soehartono, Irawan. 2004. Metode penelitian Sosial. Bandung: PT Remaja Rosdakarya

Tim Edukasi, 2005, Undang-undang Republik Indonesia Nomor 32 Tahun 2004, Tentang Pemerintahan Daerah, Yogyakarta : Pondok Edukasi,

Tricahyo, 2009, Reformasi Pemilu, Malang : In-Trans Publishing

Topo Santoso, 2006, Tindak Pidana Pemilu, Jakarta : Penerbit Sinar Grafika,

Wahidin, 2008, Mengawasi Pemilihan Umum Kepala Daerah, Yogyakarta: Pustaka Pelajar 